\title{
Extensive immigration from compensatory hatchery releases into wild Atlantic salmon population in the Baltic sea: spatio-temporal analysis over 18 years
}

\author{
A Vasemägi ${ }^{1,2}$, R Gross $^{3}$, T Paaver ${ }^{3}$, M-L Koljonen ${ }^{4}$ and J Nilsson ${ }^{1}$ \\ ${ }^{1}$ Department of Aquaculture, Swedish University of Agricultural Sciences, S-901 83 Umeå, Sweden; ${ }^{2}$ Institute of Zoology and \\ Hydrobiology, University of Tartu, 51014 Tartu, Estonia; ${ }^{3}$ Department of Fish Farming, Institute of Animal Science, Estonian \\ Agricultural University, 51014 Tartu, Estonia; ${ }^{4}$ Finnish Game and Fisheries Research Institute, FIN-00721 Helsinki, Finland
}

\begin{abstract}
Genetic homogenization has been recognized as a serious threat in an increasing number of species, including many salmonid fishes. We assessed the rate and impact of immigration from the main hatchery stocks of Atlantic salmon in the Gulf of Bothnia into one of the largest wild salmon populations in the Baltic Sea, the River Vindelälven, within a temporal framework of 18 years (from 1985-2003). We provide genetic evidence based on mtDNA and microsatellite markers, using mixed-stock analysis, that a large proportion $(66 \%)$ of fin-damaged spawners $(n=181)$ caught in the Ume/ Vindelälven during 1997-2003 originated from the hatcheries in the Rivers Ångermanälven, Luleälven and Ljusnan. The maximum-likelihood estimate of immigration rate from these
\end{abstract}

hatcheries into the wild Vindelälven population was 0.068 (95\% Cl 0.021-0.128) over the studied time period (19852003) and reached up to a quarter $(m=0.249,95 \% \mathrm{Cl}$ $0.106-0.419)$ of the total population during 1993-2000. This resulted in significant $(P<0.01)$ genetic homogenization trend between the wild Vindelälven population and hatchery stocks of the Ångermanälven and Luleälven. Our results demonstrate extensive straying from geographically distant hatchery releases into wild salmon population and emphasize the genetic risks associated with current large-scale stocking practices in the Baltic Sea.

Heredity (2005) 95, 76-83. doi:10.1038/sj.hdy.6800693

Published online 4 May 2005

Keywords: genetic homogenization; gene flow; straying; mixed stock analysis; Salmo salar, microsatellite

\section{Introduction}

Genetic homogenization reduces the spatial component of genetic diversity and has been recognized as a serious threat in increasing number of species (Olden et al, 2004). Human-mediated interbreeding between previously discrete populations can reduce the fitness of populations by homogenizing unique gene pools and disrupting local adaptations (Utter, 2001; Allendorf et al, 2001). This effect is of particular concern in Atlantic salmon (Salmo salar L.) because both intentional and unintentional (eg farm escapes) introductions are common throughout its distribution. The proportion of escaped Atlantic salmon from the aquaculture industry has been estimated to comprise $20-40 \%$ of salmon caught in the salmon fishery of North Atlantic (Hansen et al, 1999), and hybridization between domesticated and wild fish has been generally recognized as a severe threat to indigenous gene pools of native populations (eg Hindar et al, 1991; Einum and Fleming, 1997; McGinnity et al, 2003).

Currently, $80-90 \%$ of the Atlantic salmon in the Baltic Sea originates from hatcheries (ICES, 2003). The main reason for the decline in wild salmon populations in the

Correspondence: A Vasemägi, Department of Aquaculture, Swedish University of Agricultural Sciences, S-901 83 Umeå, Sweden.

E-mail:anti.vasemagi@vabr.slu.se

Received 2 September 2004; accepted 8 March 2004; published online 4 May 2005
Baltic Sea has been the construction of power plants and dams. Large-scale 'compensatory' hatchery reproduction programmes have been established based on brood-fish of native, non-native or mixed origin. However, it is widely accepted that many hatchery farming and release practices increase the amount of straying (reviewed by Quinn, 1993). For hatchery-reared Atlantic salmon, more than twice the straying rate of wild conspecifics has been reported (Jonsson et al, 2003). Nevertheless, the largescale release practices in the Baltic Sea have not been recognized as a potential threat to indigenous gene pools.

In this study, we used genetic markers to assess the rate and impact of immigration from compensatory hatchery releases into one of the largest wild Atlantic salmon populations in the Baltic Sea, the River Vindelälven (average annual run size 1447 spawners), which is a tributary to the River Umeälven and joins it about $30 \mathrm{~km}$ from the coast. The Ume/Vindelälven system supports both wild and reared Atlantic salmon. The hatchery stock of the Umeälven originates from the wild Vindelälven population and about 100000 reared smolts (with adipose fins removed since 1971) are released annually to compensate for lost production caused by power plant dams. A fish-trap below the Norrfors hydroelectric dam $20 \mathrm{~km}$ upstream from the river mouth enables complete assessment of all ascending salmon. During the second half of 1990s, an increasing number of salmon with damaged fins and scales have been detected, characteristic of intensive hatchery-rearing 
practices (see electronic appendix http://www.eau.ee/ $\mathrm{lki} / \mathrm{kalakasv} /$ supplement2/). It was suspected that these fish might originate from releases of non-native hatcheries, which do not mark their smolts by removing adipose fin. The first aim of the present study was to reveal the origin of these suspected non-native hatchery fish in the Ume/Vindelälven by using mtDNA and microsatellite markers. Secondly, we estimated the rate and effect of immigration on the genetic composition of the wild Vindelälven salmon population during the period from 1985 to 2003.

\section{Materials and methods}

\section{Salmon samples}

Samples of the suspected immigrants (ascending adult salmon with intact adipose fin but with damaged fins and scales, total of 181 fish) were collected in the Norrfors fish-trap of the Ume/Vindelälven (Figure 1) during the period from 1997 to 2003 (1997 $n=37 ; 1998$ $n=34 ; 1999 n=42 ; 2000 / 2001 n=27 ; 2002 / 2003 n=41)$. Baseline populations for the mixed stock analysis were chosen to represent all major hatchery stocks of Gulf of Bothnia from which the suspect fish may have originated. These nine hatchery stocks (Table 1, Figure 1) contribute approximately $89 \%$ of all artificial smolt production in the Gulf of Bothnia.

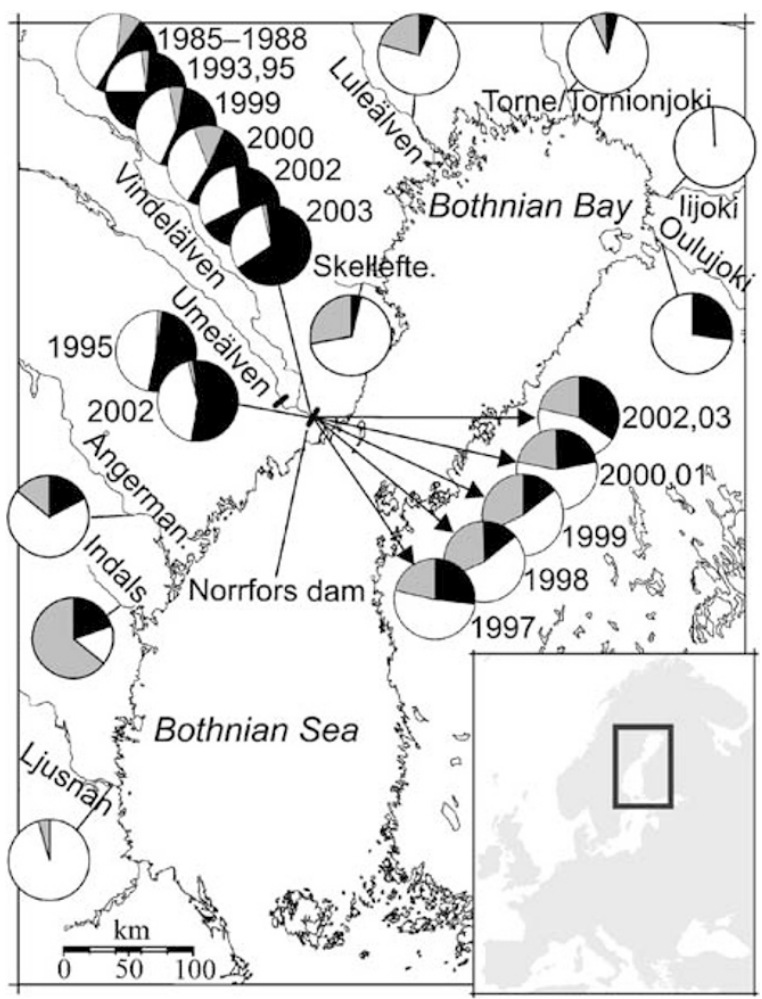

Figure 1 Map of sampling locations with pie diagrams showing the spatio-temporal distribution of mtDNA haplotype frequencies among studied Atlantic salmon populations. Haplotype frequencies of the suspected immigrants with damaged fins, caught below the Norrfors dam in the Ume/Vindelälven are indicated by arrows. The haplotypes AABA, BBBB and AAAA are designated by white, grey and black colour, respectively.
To assess the immigration rate and potential genetic impact of compensatory releases on the wild Vindelälven population, a total of 431 ascending adults of putative wild and hatchery origin (discriminated by the presence or absence of the adipose fin, respectively) caught in the Norrfors fish-trap during 1985-2003 were sampled (Table 1).

\section{DNA analyses}

Total DNA was extracted from frozen or ethanolpreserved adipose/muscle tissue (Laird et al, 1991). Extraction of DNA from dried scale samples collected during 1985-1988 from the Ume/Vindelälven was performed using a QIAGEN DNeasy Tissue Kit.

Six microsatellite loci (Ssa202, Ssa197, Ssa171, Ssa289, SSOSL417, SSOSL85) were amplified according to the PCR conditions of Koljonen et al (2002) and genotyped by using denaturing polyacrylamide gel electrophoresis or a CEQ8000 capillary sequencer (Beckman Coulter). For the dried scale samples, an increased number of PCR cycles (35-40) was used. Reference samples with known genotypes were used throughout the analysis to ensure consistent scoring of allele sizes.

RFLP analysis of the mtDNA ND1 gene region was carried out according to Nilsson et al (2001) except for the dried scales samples (1985-1888) where specific primers (Knox et al, 2002) were used to amplify shorter ND1 gene fragments suitable for the analysis of partially degraded DNA; they contained all known polymorphisms. The mtDNA haplotypes were designated as in Nielsen et al (1996).

\section{Statistical analyses}

Deviations from Hardy-Weinberg (H-W) equilibrium expectations at microsatellite loci were tested using an exact test approximation (Guo and Thompson, 1992) including a test for heterozygote deficiency as implemented in GENEPOP 3.1b (Raymond and Rousset, 1995). Multilocus estimates of significance for $\mathrm{H}-\mathrm{W}$ equilibrium were obtained using Fisher's exact test. Genetic differentiation between samples at microsatellite loci was quantified using Weir and Cockerham (1984) $F_{\mathrm{ST}}$ estimates and their significance was tested by permuting individuals between samples using ARLEQUIN 2.0 software (Schneider et al, 2000). Additionally, exact tests for differences in microsatellite allele frequencies were performed as implemented in GENEPOP 3.1b. The 25th and 75th percentiles for the $F_{\mathrm{ST}}$ estimates were calculated by bootstrapping individual genotypes within temporal samples (2000 replicates) using software POPTOOLS 2.6 (http://www.cse.csiro.au/poptools/). Homogeneity of mtDNA haplotype frequencies between samples was tested using a chi-square test. Bonferroni adjustments (Rice, 1989) were applied to correct for the effect of multiple tests.

A Bayesian approach of mixed-stock analysis (MSA) developed by Pella and Masuda (2001) and implemented in the software package BAYES (ftp://wwwabl.afsc. noaa.gov/sida/mixture-analysis/bayes) was used for estimating the proportions of non-native fish among suspected immigrants in the Ume/Vindelälven based on variation at microsatellite loci and the mitochondrial ND1 gene. Nine hatchery stock from the Gulf of Bothnia were used as baseline samples (Table 1). The Bayesian 
Table 1 Information about the studied salmon samples

\begin{tabular}{|c|c|c|c|c|c|}
\hline \multirow[t]{2}{*}{ Population/stock } & \multirow[t]{2}{*}{ Abbreviation } & \multirow[t]{2}{*}{ Year of sampling } & \multirow[t]{2}{*}{ Status } & \multicolumn{2}{|c|}{ Sample size } \\
\hline & & & & Microsatellites & $m t D N A$ \\
\hline Oulujoki & OUL & 1997 & Hatchery & 58 & 58 \\
\hline Iijoki & IIJ & 1997, 1999 & Hatchery & 60 & 15 \\
\hline Torne/Tornionjoki & TOR & 1994,1995 & Hatchery, wild & 61 & 61 \\
\hline Luleälven & LUL & 1995, 1997 & Hatchery & 60 & 60 \\
\hline Skellefteälven & SKE & 1995, 1996 & Hatchery & 44 & 44 \\
\hline Ångermanälven & ÅNG & 1995 & Hatchery & 59 & 59 \\
\hline Indalsälven & IND & 1995, 1997 & Hatchery & 64 & 64 \\
\hline Ljusnan & LJU & 1997, 1998 & Hatchery & 50 & 50 \\
\hline \multirow[t]{6}{*}{ Vindelälven } & VIN & 1985, 1986, 1988 & Wild & 53 & 49 \\
\hline & & 1993,1995 & Wild & 65 & 65 \\
\hline & & 1999 & Wild & 62 & 54 \\
\hline & & 2000 & Wild & 40 & 39 \\
\hline & & 2002 & Wild & 67 & 56 \\
\hline & & 2003 & Wild & 48 & 48 \\
\hline \multirow[t]{2}{*}{ Umeälven } & UME & 1995 & Hatchery & 48 & 48 \\
\hline & & 2002 & Hatchery & 48 & 48 \\
\hline $\begin{array}{l}\text { Suspected immigrants caught in } \\
\text { the Ume/Vindelälven }\end{array}$ & FINDAM & 1997-2003 & $?$ & 181 & 180 \\
\hline
\end{tabular}

approach of MSA calculates the posterior probability distributions of the population composition in the mixture sample assuming $\mathrm{H}-\mathrm{W}$ and linkage equilibrium. It has been demonstrated that the Bayesian implementation of MSA results in more accurate estimates than commonly used likelihood methods that ignore baseline sampling error (Pella and Masuda, 2001). In addition, when the stock-mixture proportions are uneven, the Bayesian approach has a smaller bias than the likelihood methods that tend to underestimate the contribution from abundant populations and overestimate the proportion from less common stocks (Pella and Masuda, 2001). To determine the appropriate length of the MCMC chains and to monitor convergence of multiple chains, standard procedures were followed as recommended in the BAYES user manual (5000 iterations in each of nine independent chains, burn-in period of 2500 iterations).

Immigration rates $(m)$ from non-native hatcheries into the wild Vindelälven population during the period from 1985 to 2003 were estimated by maximum-likelihood method developed by Wang and Whitlock (2003) and implemented in the computer program MLNE 1.0 (http:/ / www.zoo.cam.ac.uk/ioz/software.htm). Temporally spaced samples from the Vindelälven were divided into four groups: (i) 1985, 1986 and 1988; (ii) 1993 and 1995; (iii) 1999 and 2000 (iv) 2002 and 2003, and a mean generation length of 4.5 years was assumed.

The statistical significance of the temporal decline in $F_{\mathrm{ST}}$ estimates between the wild $\mathrm{R}$. Vindelälven population and potential sources of immigrants (non-native hatchery stocks) was tested using Monte-Carlo simulations similar to those of Hutchinson et al (2003). Briefly, individuals from temporally spaced samples were pooled and subsamples with the same size as in the observed data set were randomly formed using the software POPTOOLS 2.6. A linear regression coefficient was calculated, based on $F_{\mathrm{ST}}$ estimates between the randomized subsamples of the Vindelälven and potential donor stocks of immigrants. The procedure was repeated 2000 times and the observed regression coefficient was then compared with the distribution obtained from randomly reordered data to evaluate whether the observed pattern could be explained by chance alone.

To illustrate the expected temporal decline in $F_{\mathrm{ST}}$ estimates between the wild Vindelälven population and potential sources of immigrants, different rates of unidirectional gene flow into the $R$. Vindelälven population were simulated (four generations, 2000 replicates). Samples collected during 1985-1995 from the wild Vindelälven population were pooled and resampled with replacement to serve as a basis (generation 0) for subsequent introgression simulations using POPTOOLS 2.6.

\section{Results}

\section{$\mathrm{H}-\mathrm{W}$ equilibrium and level of differentiation}

No significant deviations from $\mathrm{H}-\mathrm{W}$ equilibrium across the six microsatelllite loci were observed in wild or hatchery samples from the Ume/Vindelälven. Temporal samples of the wild Vindelälven population (1985-2003) were not significantly differentiated from each other at mtDNA or across the six microsatelllite loci $\left(F_{\mathrm{ST}}=0\right.$ 0.008). However, the exact test for differences in microsatellite allele frequencies between temporal samples of the Vindelälven population resulted in five significant $(P<0.05)$ pairwise comparisions out of 15 (Table 2$).$ Significant temporal variation was found between two Umeälven hatchery samples (1995 vs 2002) at the microsatellite loci (exact test $P<0.001 ; \quad F_{\mathrm{ST}}=0.014$, $P<0.01)$ but not the mtDNA. The differences between the wild Vindelälven samples and nine baseline hatchery populations were highly significant $(P<0.001)$ for all pairwise comparisions using exact tests. Significant differentiation between the Vindelälven and the nine hatchery samples was also detected in the test based on permuting individuals between samples $\left(F_{\mathrm{ST}}=0.01-\right.$ $0.117 ; P<0.05)$, except for the pairwise comparison of VIN 1985, 1986, 1988 and IND 1995, 1997 sample $\left(F_{\mathrm{ST}}=0.001 ; P>0.05\right)$ (Table 2$)$. Genetic diversity indices 
for the microsatellite loci and the mitochondrial ND1 haplotype frequencies are provided in Table 3.

\section{Genetic origin of suspected immigrants}

Highly significant genetic differentiation at mtDNA $(P<0.001$; Figure 1$)$ and at four microsatellite loci out of six (exact test $P<0.001 ; F_{\mathrm{ST}}=0.011$ across six loci, $P<0.001$ ) was detected between the fin-damaged and all other adult salmon collected in the Norrfors fish-trap of the Umeälven, which suggests the presence of nonnative individuals among the damaged fish. This conclusion was further supported by a significant $(P<0.01)$ deficiency of heterozygotes among the findamaged fish, which is typical of a mixture of populations that differ in allele frequencies (a Wahlund effect).

The results of MSA indicated that majority $(66 \%)$ of the fin-damaged salmon caught in the Ume/Vindelälven during 1997-2003 originated from hatcheries from the Ångermanälven (37\%), Luleälven (21\%) and Ljusnan $(8 \%)$, while approximately $30 \%$ of fishes classified are of Ume/Vindelälven origin (Table 4). The estimated contribution of five other hatcheries was not significantly different from zero.

Temporal and spatial analysis of immigration Maximum-likelihood estimates of immigration from the three major hatchery contributors (the Angermanälven, Luleälven and Ljusnan stocks) into the wild Vindelälven population were significantly higher than zero throughout the study period $(m=0.068,95 \%$ CI $0.021-0.128)$ as well as for shorter time intervals (Figure 2). Increased immigration rate was observed from 1993 to 2000 $(m=0.249,95 \%$ CI $0.106-0.419)$. The estimate of immigration from the five other non-native hatcheries into the wild Vindelälven population was marginal and not significantly different from zero $(m=0.01,95 \%$ CI 0 0.047).

\section{Genetic homogenization trend}

A significant temporal decline in $F_{\mathrm{ST}}$ estimates between samples of wild Vindelälven population and Luleälven $(b=-0.00044, \quad P<0.01)$ and Ångermanälven $(b=$ $-0.00037, P<0.01)$ hatchery stocks, which contributed the major part of the fin-damaged strays, was observed (Figure 3). Simulations using different unidirectional migration rates $\left(m_{1}=0.07, m_{2}=0.25\right)$ from hatchery stocks of the Angermanälven, Luleälven and Ljusnan (in the ratio $4: 2: 1$, respectively) into the wild Vindelälven population showed the sharpest decrease in $F_{\mathrm{ST}}$ values after the first generation and relatively slow decline in $F_{\mathrm{ST}}$ when $m \leq 0.07$ (Figure 3).

\section{Discussion}

\section{Sources of immigrants}

This study provides genetic evidence of immigration from geographically distant compensatory hatchery releases into a wild Atlantic salmon population (from the Vindelälven) in the Baltic Sea by using two independent data sets (fin-damaged spawners from 1997 to 2003, and returning adults without obvious damage from 1985 to 2003) and different analytical procedures (mixed stock analysis, maximum likelihood estimation of immigration). We showed that a large 
Table 3 Summary statistics of microsatellite and mtDNA markers

\begin{tabular}{|c|c|c|c|c|c|c|c|c|c|c|c|c|c|c|c|c|c|c|}
\hline Locus & & $\begin{array}{c}\text { TOR } \\
1994,1995\end{array}$ & $\begin{array}{c}\text { IIJ } \\
1997,1999\end{array}$ & $\begin{array}{l}\text { OUL } \\
1997\end{array}$ & $\begin{array}{c}\text { LUL } \\
\text { 1995, } 1997\end{array}$ & $\begin{array}{c}\text { SKE } \\
1995,1996\end{array}$ & $\begin{array}{l}\AA N G \\
1995\end{array}$ & $\begin{array}{c}\text { IND } \\
1995,1997\end{array}$ & $\begin{array}{c}\text { LJU } \\
1997,1998\end{array}$ & $\begin{array}{c}\text { VIN } \\
1985,1986,1988\end{array}$ & $\begin{array}{c}\text { VIN } \\
1993,1995\end{array}$ & $\begin{array}{l}\text { VIN } \\
1999\end{array}$ & $\begin{array}{l}V I N \\
2000\end{array}$ & $\begin{array}{l}V I N \\
2002\end{array}$ & $\begin{array}{l}V I N \\
2003\end{array}$ & $\begin{array}{l}\text { UME } \\
1995\end{array}$ & $\begin{array}{l}U M E \\
2002\end{array}$ & $\begin{array}{l}\text { FINDAM } \\
\text { 1997-2003 }\end{array}$ \\
\hline \multirow{4}{*}{ Ssa171 } & $N$ & 61 & 58 & 58 & 60 & 41 & 57 & 64 & 50 & 52 & 50 & 61 & 39 & 64 & 43 & 48 & 47 & 170 \\
\hline & $A$ & 10 & 9 & 5 & 11 & 5 & 8 & 9 & 9 & 8 & 6 & 7 & 8 & 7 & 5 & 6 & 5 & 10 \\
\hline & $H_{\mathrm{O}}$ & 0.689 & 0.466 & 0.172 & 0.517 & 0.293 & 0.614 & 0.641 & 0.58 & 0.28 & 0.16 & 0.4 & 0.342 & 0.254 & 0.372 & 0.333 & 0.234 & 0.324 \\
\hline & $H_{\mathrm{E}}$ & 0.677 & 0.496 & 0.194 & 0.502 & 0.307 & 0.565 & 0.624 & 0.557 & 0.283 & 0.172 & 0.386 & 0.405 & 0.383 & 0.399 & 0.333 & 0.219 & 0.326 \\
\hline \multirow[t]{4}{*}{ Ssa197 } & $N$ & 61 & 60 & 57 & 59 & 44 & 57 & 62 & 47 & 67 & 50 & 62 & 40 & 65 & 43 & 48 & 43 & 169 \\
\hline & $A$ & 11 & 13 & 10 & 14 & 11 & 13 & 13 & 12 & 13 & 13 & 13 & 14 & 11 & 11 & 13 & 10 & 15 \\
\hline & $H_{\mathrm{O}}$ & 0.869 & 0.867 & 0.772 & 0.932 & 0.818 & 0.737 & 0.806 & 0.83 & 0.833 & 0.78 & 0.823 & 0.821 & 0.813 & 0.881 & 0.875 & 0.81 & 0.852 \\
\hline & $H_{\mathrm{E}}$ & 0.889 & 0.885 & 0.781 & 0.894 & 0.899 & 0.821 & 0.802 & 0.863 & 0.862 & 0.825 & 0.854 & 0.854 & 0.813 & 0.854 & 0.838 & 0.789 & 0.873 \\
\hline \multirow[t]{4}{*}{ Ssa202 } & $N$ & 61 & 57 & 55 & 60 & 42 & 58 & 64 & 50 & 58 & 50 & 62 & 38 & 65 & 44 & 47 & 44 & 170 \\
\hline & $A$ & 8 & 5 & 7 & 7 & 7 & 8 & 7 & 7 & 7 & 6 & 6 & 6 & 7 & 7 & 7 & 6 & 8 \\
\hline & $H_{\mathrm{O}}$ & 0.607 & 0.491 & 0.764 & 0.783 & 0.643 & 0.707 & 0.75 & 0.84 & 0.672 & 0.72 & 0.613 & 0.514 & 0.723 & 0.75 & 0.489 & 0.545 & 0.718 \\
\hline & $H_{\mathrm{E}}$ & 0.652 & 0.538 & 0.763 & 0.723 & 0.742 & 0.704 & 0.716 & 0.744 & 0.626 & 0.666 & 0.587 & 0.688 & 0.672 & 0.716 & 0.507 & 0.574 & 0.768 \\
\hline \multirow[t]{4}{*}{ Ssa289 } & $N$ & 60 & 60 & 55 & 60 & 44 & 59 & 64 & 48 & 63 & 50 & 62 & 40 & 60 & 42 & 48 & 48 & 169 \\
\hline & $A$ & 4 & 4 & 4 & 5 & 4 & 6 & 5 & 6 & 5 & 6 & 4 & 5 & 5 & 5 & 5 & 4 & 5 \\
\hline & $H_{\mathrm{O}}$ & 0.583 & 0.583 & 0.691 & 0.75 & 0.568 & 0.78 & 0.734 & 0.563 & 0.651 & 0.86 & 0.645 & 0.744 & 0.75 & 0.786 & 0.771 & 0.667 & 0.744 \\
\hline & $H_{\mathrm{E}}$ & 0.597 & 0.512 & 0.694 & 0.748 & 0.644 & 0.762 & 0.716 & 0.755 & 0.734 & 0.744 & 0.724 & 0.742 & 0.742 & 0.76 & 0.751 & 0.678 & 0.753 \\
\hline \multirow[t]{4}{*}{ SSOSL85 } & $N$ & 45 & 59 & 56 & 59 & 35 & 56 & 64 & 50 & 67 & 50 & 61 & 40 & 62 & 42 & 48 & 46 & 168 \\
\hline & $A$ & 7 & 11 & 6 & 9 & 4 & 7 & 9 & 11 & 9 & 4 & 6 & 6 & 6 & 6 & 6 & 5 & 11 \\
\hline & $H_{\mathrm{O}}$ & 0.844 & 0.864 & 0.875 & 0.729 & 0.829 & 0.518 & 0.719 & 0.7 & 0.612 & 0.6 & 0.617 & 0.769 & 0.742 & 0.634 & 0.396 & 0.591 & 0.708 \\
\hline & $H_{\mathrm{E}}$ & 0.793 & 0.821 & 0.737 & 0.797 & 0.644 & 0.659 & 0.659 & 0.786 & 0.585 & 0.551 & 0.617 & 0.692 & 0.679 & 0.616 & 0.43 & 0.598 & 0.721 \\
\hline \multirow[t]{4}{*}{ SSOSL417 } & $N$ & 50 & 59 & 51 & 60 & 44 & 59 & 64 & 50 & 56 & 50 & 62 & 40 & 64 & 43 & 47 & 46 & 169 \\
\hline & $A$ & 8 & 9 & 7 & 9 & 9 & 12 & 11 & 10 & 12 & 11 & 12 & 9 & 11 & 10 & 11 & 8 & 15 \\
\hline & $H_{\mathrm{O}}$ & 0.84 & 0.746 & 0.725 & 0.883 & 0.841 & 0.864 & 0.844 & 0.68 & 0.833 & 0.82 & 0.836 & 0.8 & 0.71 & 0.814 & 0.766 & 0.891 & 0.805 \\
\hline & $H_{\mathrm{E}}$ & 0.81 & 0.793 & 0.777 & 0.832 & 0.823 & 0.875 & 0.869 & 0.698 & 0.824 & 0.823 & 0.821 & 0.812 & 0.795 & 0.801 & 0.805 & 0.815 & 0.851 \\
\hline \multirow[t]{4}{*}{ mtDNA } & $N$ & 61 & 5 & 58 & 60 & 44 & 59 & 64 & 50 & 67 & 50 & 54 & 39 & 58 & 44 & 48 & 48 & 180 \\
\hline & AAAA & 0.049 & 0 & 0.276 & 0.067 & 0.045 & 0.169 & 0.203 & 0 & 0.582 & 0.68 & 0.537 & 0.513 & 0.69 & 0.682 & 0.5 & 0.542 & 0.228 \\
\hline & AABA & 0.885 & 1 & 0.724 & 0.717 & 0.682 & 0.678 & 0.156 & 0.96 & 0.358 & 0.28 & 0.407 & 0.359 & 0.31 & 0.295 & 0.479 & 0.438 & 0.511 \\
\hline & BBBB & 0.066 & 0 & 0 & 0.217 & 0.273 & 0.153 & 0.641 & 0.04 & 0.06 & 0.04 & 0.056 & 0.128 & 0 & 0.023 & 0.021 & 0.021 & 0.261 \\
\hline
\end{tabular}

$\left(n\right.$ - number of individuals studied; $A$ - observed number of alleles per locus and sample; observed $\left(H_{\mathrm{O}}\right)$ and expected $\left(H_{\mathrm{E}}\right)$ heterozygosity; AAAA, AABA, BBBB - mtDNA haplotypes according to the nomenclature of Nielsen et al (1996)) 
Table 4 Proportions (contributions) of hatchery stocks among suspected fin-damaged immigrants $(n=181)$ caught in the River Ume/ Vindelälven during 1997-2003 as revealed by mixed-stock analysis

\begin{tabular}{|c|c|c|c|c|c|}
\hline \multirow[t]{2}{*}{ Population/stock } & \multicolumn{2}{|c|}{ Mixed-stock analysis } & \multicolumn{3}{|c|}{ Posterior quantiles } \\
\hline & Mean & $S D$ & $2.5 \%$ & Median & $97.5 \%$ \\
\hline Oulujoki & 0.004 & 0.009 & 0 & 0 & 0.030 \\
\hline Iijoki & 0.001 & 0.004 & 0 & 0 & 0.014 \\
\hline Torne/Tornionjoki & 0.002 & 0.006 & 0 & 0 & 0.021 \\
\hline Luleälven & 0.214 & 0.063 & 0.101 & 0.210 & 0.345 \\
\hline Skellefteälven & 0.008 & 0.017 & 0 & 0 & 0.059 \\
\hline Ångermanälven & 0.373 & 0.075 & 0.234 & 0.371 & 0.526 \\
\hline Indalsälven & 0.018 & 0.024 & 0 & 0.008 & 0.084 \\
\hline Ljusnan & 0.080 & 0.032 & 0.027 & 0.077 & 0.152 \\
\hline Úme/Vindelälven (combined) & 0.300 & 0.052 & 0.202 & 0.299 & 0.405 \\
\hline
\end{tabular}

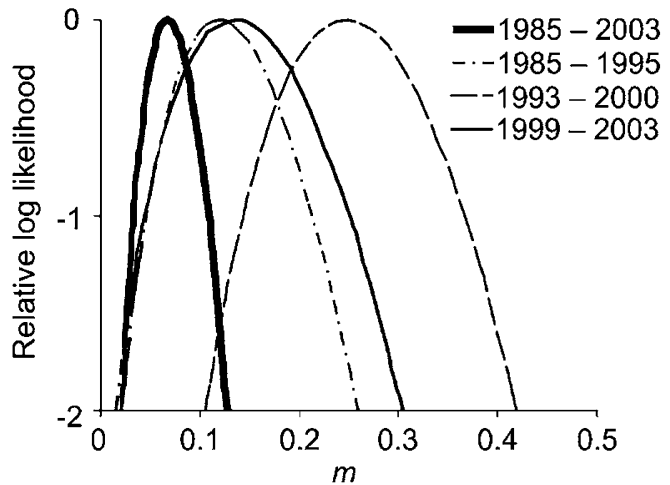

Figure 2 Relative log-likelihood curves of estimated immigration rates from the three major hatchery contributors (a pooled sample of the Angermanälven, Luleälven and Ljusnan stocks) into the wild Vindelälven population during the different time periods from 1985 to 2003. The area under the curve corresponds to $95 \%$ confidence interval of estimated immigration rate.

proportion (66\%) of fin-damaged salmon spawners (adipose fin present) caught $20 \mathrm{~km}$ upstream in the Ume/Vindelälven originated from three non-native hatchery releases. Detection of the Luleälven hatchery as one of the major immigrant sources was not unexpected for several reasons. First, the Luleälven hatchery production (over half a million smolts per year) is the second largest in the Baltic Sea. Second, the Luleälven hatchery stock has been formed by mixing salmon from different origins (from the rivers Luleälven, Ångermanälven, Skellefteälven, Indalsälven and Ume/ Vindelälven). Candy and Beacham (2000) showed that artificially made hybrid stocks of chinook salmon (Oncorhynchus tshawytscha) exhibited three times higher straying rate than the native stock, when released at the same time and location, suggesting that hybridization could lead to an elevation of straying. The amount of hatchery releases into the Angermanälven is around 200000 smolts per year, being approximately twice as much as released annually from the Skellefteälven and Umeälven hatcheries. The third immigrant source, the Ljusnan, releases approximately 185000 smolts per year but being more distant from the Ume/Vindelälven it contributed only a small proportion of the suspected immigrants.

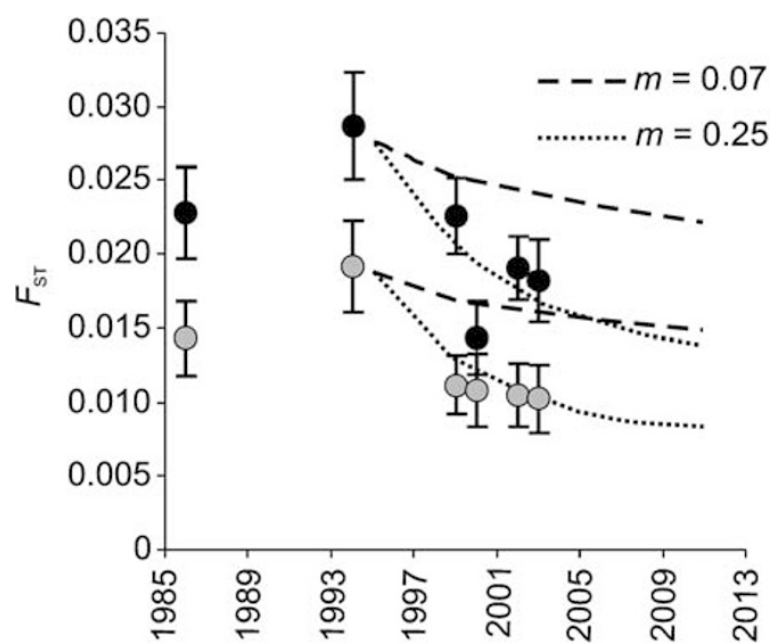

Figure 3 Temporal changes in $F_{\mathrm{ST}}$ estimates between wild Vindelälven salmon population (1985-2003) and the Luleälven hatchery stock (black bullets), and Angermanälven hatchery stock (grey bullets). Whiskers indicate the 25th and 75th percentiles of $F_{\mathrm{ST}}$ estimates. Simulated temporal declines in $F_{\mathrm{ST}}$ estimates as a result of unidirectional migration from three major sources of immigrants (the Ångermanälven, Luleälven and Ljusnan hatcheries) into the Vindelälven population are shown by dashed and dotted lines assuming two different immigration rates 0.07 and 0.25 , respectively.

As our temporal sampling strategy was based on returning adult salmon in the Ume/Vindelälven, the current study does not demonstrate interbreeding between hatchery strays and native salmon. Furthermore, the proportion of non-native adult salmon caught in a non-natal river is not necessarily equivalent to the effective gene flow into native population (eg Griffith et al, 1999). For that reason, the key question is, how big a proportion of non-native hatchery fish actually spawned successfully (interbred) in the Vindelälven. Considering that the number of juveniles with obvious damage among strays is unknown, it is possible that the identified non-native fish constituted only a small proportion of the total number of immigrants. Consistent with this possibility, immigration rate estimates were significantly higher than zero over all the time periods studied, reaching up to a quarter of the total effective population size during 1993-2000. Moreover, as expected 
in case of increased immigration, a significant temporal decline in genetic differentiation between the wild Vindelälven population and two largest immigrant sources (the Angermanälven and Luleälven hatcheries) was observed. Thus, our results show that current hatchery releases may threaten genetic integrity of even geographically distant wild salmon populations in the Baltic Sea and caution against large-scale 'sea ranching' in the Baltic Sea.

\section{Increased genetic impact of hatchery releases: \\ M74 hypothesis}

Elevated immigration rate into the Ume/Vindelälven system during the period from 1993 to 2000 and the decline in genetic differentiation between the wild Vindelälven population and two major immigrant sources after 1995 raises the obvious question why this happened just during this period, given that large-scale hatchery releases had previously been carried out in the Baltic Sea for more than 40 years. As one possible hypothesis, we suggest that the increased genetic impact of compensatory releases on the wild populations could be associated with the outbreak of M74 disease syndrome in the Baltic during 1990s (Hansson et al, 2001). Estimated M74 mortality among salmon fry in the Umeälven hatchery was highest during 1992-1996 ranging from 69 to $90 \%$ (ICES, 2003). M74 is associated with the low levels of vitamin B1 (thiamine) in salmon eggs and fry, and hatcheries have routinely used thiamine treatment of fry since 1995 to prevent the development of M74 syndrome. As a result, the production of hatchery-reared salmon has stayed high and relatively stable, while the effect of M74 on the wild populations may have been devastating as was observed in the Vindelälven, where the lowest parr density estimates were recorded during the years of high M74 incidence. M74 might, therefore, have been responsible for changing the ratio between breeders of wild and hatchery origin and could, hence, have increased the genetic impact of compensatory releases on wild populations during the second half of 1990s. However, the cause of the increase in non-native hatchery salmon with fin and scale damage in the Ume/Vindelälven during the second part of 1990s remains unclear.

\section{Acknowledgements}

We are grateful to $\mathrm{H}$ Köningsson for her assistance in the laboratory, L Karlsson for providing scale samples and A Forssèn for discerning, photographing and sampling fin-damaged salmon. This work was supported by grants from the Royal Swedish Academy of Agriculture and Forestry, Oscar and Lili Lamm's Foundation, Kempe Foundation and Estonian Science Foundation (Grant no. 5729).

\section{References}

Allendorf FW, Leary RF, Spruell P, Wenburg JK (2001). The problems with hybrids: setting conservation guidelines. Trends Ecol Evol 16: 613-622.

Candy JR, Beacham TD (2000). Patterns of homing and straying in southern British Columbia coded-wire tagged chinook salmon (Oncorhynchus tshawytscha) populations. Fish Res 47: 41-56.
Einum S, Fleming IA (1997). Genetic divergence and interactions in the wild among native, farmed and hybrid Atlantic salmon. J Fish Biol 50: 634-651.

Griffith JN, Hendry AP, Quinn TP (1999). Straying of adult sockeye salmon, Oncorhynchus nerka, entering a non-natal hatchery. Fish Bull 97: 713-716.

Guo SW, Thompson EA (1992). Performing the exact test for Hardy-Weinberg proportion for multiple alleles. Biometrics 48: 361-372.

Hansen LP, Jacobsen JA, Lund RA (1999). The incidence of escaped farmed Atlantic salmon, Salmo salar L., in the Faroese fishery and estimates of catches of wild salmon. ICES J Mar Sci 56: 200-206.

Hansson S, Karlsson L, Ikonen E, Christensen O, Mitans A, Uzars D et al (2001). Stomach analyses of Baltic salmon from 1959-1962 and 1994-1997: possible relations between diet and yolk-sac-fry mortality (M74). J Fish Biol 58: 1730-1745.

Hindar K, Ryman N, Utter F (1991). Genetic effects of cultured fish on natural fish populations. Can J Fish Aquat Sci 48: 945-957.

Hutchinson WF, van Oosterhout C, Rogers SI, Carvalho GR (2003). Temporal analysis of archived samples indicates marked genetic changes in declining North Sea cod (Gadus morhua). Proc $R$ Soc Lond Ser B Biol Sci 270: 2125-2132.

ICES (2003) Report of the Baltic salmon and trout assessment working group in Karlskrona, Sweden, 2-11 April 2003. ICES CM 2003/ACFM:20.

Jonsson B, Jonsson N, Hansen LP (2003). Atlantic salmon straying from the River Imsa. J Fish Biol 62: 641-657.

Knox D, Lehmann K, Reddin DG, Verspoor E (2002). Genotyping of archival Atlantic salmon scales frorn northern Quebec and West Greenland using novel PCR primers for degraded mtDNA. J Fish Biol 60: 266-270.

Koljonen ML, Tähtinen J, Säisä M, Koskiniemi J (2002). Maintenance of genetic diversity of Atlantic salmon (Salmo salar) by captive breeding programmes and the geographic distribution of microsatellite variation. Aquaculture 212: 69-92.

Laird PW, Zijderveld A, Linders K, Rudnicki MA, Jaenisch R, Berns A (1991). Simplified mammalian DNA isolation procedure. Nucleic Acids Res 19: 4293.

McGinnity P, Prodöhl P, Ferguson A, Hynes R, Maoiléidigh N, Baker $N$ et al (2003). Fitness reduction and potential extinction of wild populations of Atlantic salmon, Salmo salar, as a result of interactions with escaped farm salmon. Proc R Soc Lond Ser B Biol Sci 270: 2443-2450.

Nielsen EE, Hansen MM, Loeschcke V (1996). Genetic structure of European populations of Atlantic salmon (Salmo salar L.) inferred from RFLP analysis of PCR amplified mitochondrial DNA. Heredity 77: 351-358.

Nilsson J, Gross R, Asplund T, Dove O, Jansson H, Kelloniemi J et al (2001). Matrilinear phylogeography of Atlantic salmon (Salmo salar L.) in Europe and postglacial colonization of the Baltic Sea area. Mol Ecol 10: 89-102.

Olden JD, Poff NL, Douglas MR, Douglas ME, Fausch KD (2004). Ecological and evolutionary consequences of biotic homogenization. Trends Ecol Evol 19: 18-24.

Pella J, Masuda M (2001). Bayesian methods for analysis of stock mixtures from genetic characters. Fish Bull 99: 151-167.

Quinn TP (1993). A review of homing and straying of wild and hatchery-produced salmon. Fish Res 18: 29-44.

Raymond M, Rousset F (1995). GENEPOP (Version 1.2): a population genetics software for exact tests and ecumenism. J Hered 86: 248-249.

Rice WR (1989). Analysing tables of statistical tests. Evolution 43: 223-225.

Schneider S, Kueffer J-M, Roessli D, Excoffier L (2000). Arlequin, version 2000. A software for population genetics 
data analysis. Genetics and Biometry Laboratory. University of Geneva: Geneva.

Utter F (2001). Patterns of subspecific anthropogenic introgression in two salmonid Genera. Rev Fish Biol Fisher 10: 265-279.
Wang J, Whitlock MC (2003). Estimating effective population size and migration rates from genetic samples over space and time. Genetics 163: 429-446.

Weir BS, Cockerham CC (1984). Estimating F-statistics for the analysis of population structure. Evolution 38: 1358-1370.

Supplementary Information accompanies the paper on Heredity website (http://www.nature.com/hdy). 